\title{
THE EQUIVALENCE AND SHIFTS IN THE INDONESIAN TRANSLATION OF ENGLISH PREPOSITIONS
}

\author{
IN, ON, AND AT. \\ Noni Marlianingsih \\ Program StudiPendidikan Bahasa Inggris \\ Fakultas Bahasa danSeniUniversitasIndraprasta PGRI \\ Pos-el: marleeanee@yahoo.co.id \\ Telepon: (021) 4803236/083872299920
}

\begin{abstract}
The aim of this study was to find out how the English prepositions in, on, and at are translated into Indonesian, and to describe the techniques used in translating. The method used in this research is descriptive qualitative. The data source were taken from the novel The Runaway Jury and its rendering in Indonesian entitled JuriPilihan. Based on this research, the English prepositions in, on, and at can be translated into Indonesian in the form of preposition. The results showed that there are three main categories namely in, on and at. The results show that the prepositions in English is $40 \%$ of the 100 data. English preposition on is $35 \%$ of the 100 data. The smallest amount, the English preposition at is $25 \%$ of the 100 data. Based on these results, we can conclude that the English prepositions in, on, and at can be translated into Indonesian become akan, dengan, di, ke, pada, tanpa, tentang, untuk, di, pada, selama, and mengenai.
\end{abstract}

Key words: Equivalence, Shifts, Translation, Preposition

\begin{abstract}
ABSTRAK
Tujuandaripenelitianiniuntukmencaritahubagaimanapreposisibahasainggrisin,

on, danatditerjemahkankebahasa Indonesia, danuntukmenjelaskanteknik yang digunakan dalammenerjemahkan. Metode yang digunakandalampenelitianiniadalahkualitatifdeskriptif. Sumber data diambildari novel "The Runaway Jury"dantelahditerjemahkandalambahasa Indonesia berjudul "JuriPilihan". Berdasarkanhasildaripenelitianini, preposisibahasainggrisin, on,danat dapatditerjemakankebahasa Indonesia dalambentukpreposisi. Hasilmenunjukkanbahwaadatigakategoriutamayaituin, ondanat. Hasil paling banyakdarianalisisinimenunjukkanbahwapreposisibahasainggrisinadalah $40 \%$ dari 100 data. Kedua, preposisibahasainggrisonadalah $35 \%$ dari 100 data. Jumlahterkecil, preposisibahasainggrisatadalah 25 $\%$ dari 100 data. Berdasarkanhasiltersebut, sehinggadapatdisimpulkanbahwapersamaandaripreposisibahasainggrisin, on, danatdapatditerjemahkankebahasa Indonesia menjadiakan, dengan, di, ke, pada, tanpa, tentang, untuk, di, pada, selama, and mengenai.
\end{abstract}

Kata kunci: persamaan, pergeseran, penerjemahan,preposisi

Jurnal Pujangga Volume 1, Nomor 2, Desember 2015 


\section{INTRODUCTION}

The preposition will be difficult to understand if it were translated word by word based on the dictionary, because it should be changed and replaced to get synonym of source language text (SLT) to target language text (TLT). Translating the meaning of preposition depend on the situation and the context of the sentences. That is why the researcher want to find out the equivalence and shifts in the translation English preposition into Indonesian.

The writer argues that the English preposition cannot be bargained even it was using in daily activities. If we were wrong in using the preposition so it will be annoying our skill to be able in speaking English fluently and became fatal, because it should be suitable with the standardization as their function. So we cannot under estimate the preposition although we always consider it as a simple word and easy to apply in the sentences.

In this study, the researcher wants to find out how the preposition in novel entitled " The Runaway Jury " written by John Grisham was translated into Indonesian. The researcher choose the novel because there are many preposition were discussed in there. Beside that the novel discuss on law that becomes interesting topic. Otherwise, the researcher want to find out the equivalence and shift in the Indonesian's preposition translation in, on, and at from English. Because there are many people still confusing when they have to apply the prepositions in the sentences.This research is important to be carried out because discuss about preposition can be considered as a useful and basic matter in translation studies. The researcherhope about this research will be giving many advantages for the development and enriching the translation studies are used by many people and universities or institutions in this world, who are interesting to learn about foreign language from other countries.

\section{METHODSTRANSLATION}

It is structural part of language which is actually in the seen in print or heard in speech. In translation the form of the source language is replaced by the form of the receptor language (target language) (Larson, 1984: 3).

"Translation develops three qualities essential to all language learning: accuracy, clarity, and flexibility. It trains the learner to search (flexibility for the most appropriate words (accuracy) to convey what is meant (clarity) ".( Duff, 1984 : 7 ).

Peter Newmark (1988:7) said that translation is a craft consisting in the attempt to replace a written message and / or statement in one language by the same message and / or statement in another language. 
Eugene A. Nida and Charles R. Taber (1982 : 12) states, translating consist in reproducing in the receptor language the closest natural equivalence of the source language message, first in terms of meaning and secondly in terms of style.

\section{The Ideal Translation}

1. Accurate: reproducing as exactly as possible the meaning of the source text.

2. Natural: using natural forms of the receptor language in a way that is appropriate to the kind of text being translated.

3. Communicative: expressing all aspects of the meaning in a way that is readily understandable to the intend audience.

Translation, then, consist of studying the lexicon, grammatical structure, communication situation, and cultural context of the source language text, analyzing it in order to determine its meaning, and then reconstructing this same meaning using the lexicon and grammatical structure which are appropriate in the receptor language and its cultural context. (Larson. 1998: 3).

The linguistic knowledge, as Tanke (in Slype et.al, 1984: 83) states, includes "terminological research "and application of grammatical rules." The language skill includes tasks of reading comprehension and creative writing as well as evaluation and appreciation.

\section{Equivalence in the Translation}

In his linguistic theory of translation, the British linguist and translation theorist, J.C. Catford argues that one of the central tasks of the translation theory is defining the nature and condition of translation equivalence (Hatim, 2001: 14). Equivalence is taken to be the basis on which source language (SL) textual material is replaced by the target language (TL) textual material according to Catford, ' replacing ' a source language meaning by a target language meaning can be achieved through formal correspondence or textual equivalence.

Eugene Nida (1979: 52) stated that translation which focus upon cognitive content in some instance upon emotive response in others may be regarded as dynamic equivalence-translation.

Proponents of equivalence -based theories of translation usually define equivalence as the relationship between a source text (ST) and a target text (TT) that allows the TT to be considered as a translation of the ST in the first place. (Baker, 1988: 77).

\section{Types of Equivalence}

\section{Formal Correspondence}

According to Catford (1965: 27) (in Hatim, 2001: 15), formal correspondence involves adhering closely to the linguistic form of the source text. It covers formal 
relationship which exist when 'a TL category can be found which occupies in the SL ', e.g. translating an adjective by an adjective.

Nida defined formal equivalence as an orientation to translation which 'focus on the message itself, in both form and content '(1964: 159 (in Hatim, 2001:19). Nida said that formal equivalence is useful in situation where the translator or interpreter may for some reason be unwilling to accept responsibility for changing the wording of the target text (e.g. diploma correspondence) (Hatim, 2001: 21).

\section{Textual Equivalence}

Textual Equivalence obtains when any TL text or portion of text is 'observed on a particular occasion to be the equivalent of a given SL text or portion of text '. E.g. translating an adjective by an adverbial phrase. Textual equivalence is obtained in cases where translation cannot be carried out by adhering closely to the linguistic form of the source text (e.g. when a preposition cannot be translated into a preposition) (ibid: 16).

\section{Dynamic Equivalence}

This type of equivalence refers to the set of procedures by means of which 'the message of the original text will be transported into the receptor language that the response of the receptor is essential like that of the original receptor' (Nida and Taber, ibid: 19).

\section{Cultural Equivalence}

Cultural equivalence is an approximate translation where a SL cultural word is translated by a TL cultural word (Newmark, 1988: 82)

\section{Functional Equivalence}

This type of equivalence is used to apply to cultural words, requires the use of cultural-free words, sometimes with a new specific term; it therefore neutralizes or generalizes the SL word; and sometimes adds a particular word.

\section{Descriptive Equivalence}

This type is obtained by describing the term of the SL (describing the function, the appearance, etc.)The Leipzig translation Scholar, Otto, Kade, puts forward a quasi-mathematical typology along the following lines (Kade 1968 (in Hatim, 2001: 29) One-to-one equivalence, when there is a single expression in TL for a single SL expression, On-to-many equivalence, when more than one TL expression is available for a single SL expression, One-to-part-of-one equivalence, when a TL expression that convers part of a concept is designed by a single SL expression, NIL equivalence, when no TL expression exist for an SL expression. 


\section{Shift or Translation}

A 'shift' (Catford term) or 'transposition' (Vinay and Darbelnet) is a translation procedure involving a change in the grammar from SL to TL (Newmark, 1988: 85). The term shifts is used in the literature to refer to changes which occur or may occur in the process of translating.

When translation cannot be carried out by adhering closely to the linguistic form of the source text, textual equivalence is achieved through what Catford calls 'translation shifts' (Hatim, 2001: 15). The concept of shifts is defined in terms of departures (from formal correspondence in the process of going from the SL to the TL '(1965: 73 in Hatim, 2001: 15).

\section{The English Preposition}

According to Greenbaum (1990: 188--200)Preposition are a closed class of items connecting two units in a sentence and specifying a relationship between them. For example: The elderly man in the raincoat (looks ill). Constitutes a complex noun phrase.

1. Although also having a nominal function, that-clauses and infinitive clauses cannot be prepositional complements.

2. In addition, there are circumstances where deferment is optimal, depending chiefly on stylistic preference. The commonest prepositions are a small number of monosyllabic items such as at, for, in, on, to, with, typically unstressed and often with reduced vowel except when deferred. But in addition there are polysyllabic preposition, some of them compounds formed historically from the monosyllabic ones (such as inside, within) or derived from particles (such as during) or adopted from other languages (such as despite, except). Thus although prepositions are a closed class in comparison with truly open classes like nouns, they are less literally a closed class than determiners or pronouns.

3. Though the relationship between two linguistic units may be wide-ranging in meaning, most of them are either spatial or figuratively derived from notions of physical space.

4. Between the nations of directional movement and static position there is a causeand-affect relation which applies equally to (a) the positive prepositions and (b) the negative preposition

5. Where places are regarded as points on a route or as institutions to which one is attached, dimension.

6. There preposition, at, on, and in, are used in expressions answering the question 'when'? And they reflect a concept of time as analogous to space. Thus at is used for point of time, where time is conceived as being 'dimensionless'.

7. Where time is regarded as a period, the usual preposition is in, reflecting analogy with two-or three-dimensional space.

8. But in expressions referring to days 
9. So too with an interval that is specifically part of a day

10. Reference to night may disregard its 'dimension ' as in

11. A phrase like in three days may be used to indicate a duration or a point three days hence

12. With at, the goal or target is usually viewed with hostility But with aim, point, and above all smile, the target can be viewed neutrally

13. Stimulus and reaction are expressed chiefly by at :

\section{The Indonesian Prepositions}

\section{Singular Preposition}

A preposition that consists of one word. The singular preposition form could be (1) basic word, such as di,danpada,dan (2) affix word, such as selama, danmengenai.

\section{The Indonesian Function Words.}

The preposition in this group only consists of one morpheme. The following examples:

$\begin{array}{ll}\text { akan } & \text { takutakankegelapan } \\ \text { dengan } & \text { pergidengantemannya } \\ \text { di } & \text { duduk dikursi } \\ \text { ke } & \text { pergikekantor } \\ \text { pada } & \text { adapadasaya } \\ \text { tanpa } & \text { tanpatersenyum } \\ \text { tentang } & \text { berbicaratentangmoneter } \\ \text { untuk } & \text { bukuuntukTono }\end{array}$

\section{The Functions of Indonesia Prepositions}

According to Alwi, (2003: 295-2-96) the preposition has a function or role to recognize various relations meaning between constituent in front of the preposition and the behind of constituent. The preposition semantic role which used to be in Indonesia language as a relation characteristic: place, allocation, reason, and or ways, actor, time, circumstances (event), and property.

\section{Relation place characteristic} di, ke, pada

Relation allocation characteristic untuk

\section{Relation event circumstances characteristic} tentang, mengenai

Relation and ways characteristic dengan 


\section{Relation time characteristic}

pada

The researcher the Indonesian prepositions or foreword; di, ke, dari, pada, mengenai, sepanjang, dandenganthat adhering closely to the English prepositions in, on, and at. The Indonesian preposition has a function or role to recognize various relations meaning between constituent in front of the preposition and the behind constituent. It is used to be as a relation characteristic: place, allocation, ways, time, and circumstances (event).

\section{Research Method}

Burns (2000) stated that "Research is a systematic investigation to find answers to a problem. Research is a professional science areas, like research in other subjects, has generally followed the traditional objective scientific method." (p.3)

There are two approaches in conducting a research, namely quantitative and qualitative approach. Terms that are commonly associated with quantitative and qualitative approaches to research are as follows:

\section{Qualitative research:}

1. advocates use of qualitative methods

2. Concerned with understanding human behavior from the actor's own frame of reference

3. Naturalistic and uncontrolled observation

4. Subjective

5. close to the data: the 'insider' perspective

6. Grounded, discovery-oriented, exploratory, expansionist, descriptive and inductive

7. process-oriented

- Valid: 'real', 'rich', and 'deep' data

- Ungeneralizable: single case studies

Assumes a dynamic reality

Quantitative research

1. advocates use of quantitative methods

2. Seek facts or causes of social without regard to the subjective states of the individuals

3. Obtrusive and controlled measurement

4. Objective

5. removed from the data: the 'outsider' perspective

6. Ungrounded, verification-oriented, confirmatory, reductionist, inferential, and 
hypothetical-deductive

7. outcome-oriented

- Reliable: 'hard', and replicable data

- Generalizable: multiple case studies

Assumes a stable reality

In line with item number 6 of qualitative research of which is stated 'descriptive', this study can belong to 'qualitative research' as there is a description of data from the sources as well as from the product of the translation of preposition in, on, and at in the novel.

One of the characteristics of qualitative research is descriptive research and a sub category of this descriptive research is documentary analysis. Document is printed paper furnishing information. Thus, the data found in the novels can be called as document because they provide the information required for the analysis of this research. In this research, the documentary analysis focused on texts from the novels which contain preposition in, on, and at. The research is employing descriptive analytical method.

The descriptive research is designed to obtain information concerning the current state of phenomenon. It is directed toward determining the nature of a situation as it exists at time of the research. There is no administration or control of a treatment as the objective is to describe 'what exists' with respect to variables or conditions in a situation.

The sources of data in this paper are the novel "the runaway jury" by John Grisham, published by Doubleday books second edition in 1997 and its rendering into Indonesian entitled "JuriPilihan" which was translated by Hidayat Saleh first edition and was published by Gramedia Pustaka Utama in 1996.

After determining the appropriate theories related to this research, the procedure refers to the process of discovering the meaning of the source language text and the translated language text. Afterward, the initial draft was prepared. Before any extensive drafting can be done, the key terms must be determined. Every text has a set of words that are crucial to the content and correct communication of the theme. It may be necessary to work the initial draft several times - that no information is wrong or omitted, that the text communicates clearly in the receptor language, and that the form chosen will communicate to the readers.

The next step is evaluation. Its purpose is threefold: accuracy, clarity and naturalness. The questions to be answered are: does the translation communicate the same meaning as the source language? Does the audience for whom the translation is 
intended understand it clearly? Is the form of the translation easy to read and does it use natural receptor language grammar and style?

Then, the research started collecting data from the original English novel as well as from its translated version in line with the theories. Samples are taken from each Indonesian equivalence of the English preposition. The technique of taken samples is purposive random sampling which means that from the available data, and the data are classified into three parts. They are translation of English prepositions in, on, and at into Indonesian preposition.

\section{Technique of Data Analysis}

\section{Editing}

Edit (fault data) Source language and target language text by comparing and editing data from Source language and target language text in full sentences for its correctness in grammar, spelling and missing words.

\section{Classifying Data}

The data are classifying into three main categories, the English preposition in and its Indonesian translations, the English preposition on and its Indonesian translations, and the English preposition at and its Indonesian translator. Each main category classified into two sub-categories, equivalence and shift, first sub-category is equivalence classified into three sub-sub-categories, formal correspondence, textual equivalence, and dynamic equivalence. Second sub-category is shift classified into four sub-sub-categories into class, structure, unit, intra-system shift.

\section{Presenting Data}

Presenting the data in the form of pie chart and tables and giving the examples of the equivalence and shift. General table are presenting the percentages of two main categories, equivalence and shift. Specific tables are presenting the one main category and the sub category.

\section{Interpreting Data}

Interpreting data are divided into two steps. First, describing the data after presented the examples of equivalence and shift. Second, explaining the reason of the categorizing data based on the theory.

\section{RESULT AND DISCUSSION}


Based on the main categories above, the biggest result of this analysis shows that the English preposition in is $40 \%$ out of 100 data. Then, the English preposition on is 35 or $35 \%$ out of 100 data. And the smallest, the English preposition at is 25 or $25 \%$ out of data.

The biggest result of the English preposition in is $40 \%$ expressed that John Grisham used to be it in his novel "The Runaway Jury". That proved the English preposition in is usually placed between words or phrases, the most usual being those of time, space (position, direction, etc.), a member of, with reference to, and condition.

The second, the result of English preposition on has less differences from the first is $35 \%$ described that the preposition on is always used in the sentences and its function to explain a certain day, street, about, and touching the surface.

The third, the English preposition at has smallest result is $25 \%$. The less of using in preposition at does not mean John Grisham dislike to apply it in his novel, but coincidentally it was so hard for the researcher to find it. The preposition at usually express the position, time, and respect.

According to the Pie chart above, the main categories of English prepositions in, on, and at and their Indonesian translations were classified into two subcategories, equivalence and shift. First sub-category is equivalence which classified into three sub-sub-categories, formal correspondence equivalence, textual equivalence, and dynamic equivalence. Second sub-category is shift which the subsub-categorize was classified into class, structure, unit, intra-system shift.

\section{The English Preposition in and its Indonesian Translations}

This study was classified into two sub-categories, equivalence and shift. First sub-category is equivalence that classified into three sub-sub-categories, formal correspondence equivalence, textual equivalence, and dynamic equivalence. Second sub-category is shift which divided into sub-sub-categories into class, structure, unit, intra-system shift.

\section{Equivalence}

Equivalence was classified into three sub-sub-categories, formal correspondence, textual, and dynamic equivalence.

\section{Formal Equivalence}

\section{Example:}

This study found that one of the sub-sub categories is formal equivalent.

SLT: (...), his words echoing in the stillness. (P. 50/L. 16)

TLT: (...), kata-katanyabergemadalamkeheningan. (P. 68/L. 3) 
SLT: She looked great intight jeans and short skirts, she looked great inanything or nothing....(P. 80/L. 10)

TLT: Iatampakhebatdengan jeans ketatdanrokpendek, iatampakhebatdenganpakaianapapunatautanpaapa pun... (P. 103-104/L. 13)

Discussion:

Based on the theory of formal equivalence above, the result of translation or in TLT should be oriented towards the ST structure, which exerts strong influence in determining accuracy and correctness. The TLT (1) in the stillness and (2) in tight jeans and in anything, we can see that the sentences followed the SLT structure and the word infor the TLT (1) and (2) have different meaning, dalamkeheningan and dengan jeans ketat. The TLT (1) and (2) are categorized into formal equivalence because the translations equal to the SLT by the form and meaning.

\section{Textual Equivalence}

\section{Example:}

SLT: (...), and it would earn millions in fees because of this selection. (P. 10/L. 5)

TLT:(...), danakanmendapatberjuta-jutadolaruangjasakarenapilihanini. (P. 19/L. 12)

SLT: (...), then watched most of the heads shake in agreement. (P. 50/L. 9)

TLT: (...), lalumenyaksikansebagianbesarkepalaitumengangguksetuju. (P. 68/L. 10)

Discussion:

The concept of shifts is the translation of target text cannot be carried out by adhering-closely to the linguistic form of the source text (e.g. when a preposition cannot be translated into a preposivction. The one of ideal translation is naturalness, using natural form of the receptor language in a way that is appropriate to the kind of text being translated. Based on the translating concepts above, TLT (3) in fees did not translate to become untukuangjasa but uangjasa, and TLT (4) in agreement did not translate to become dengansetuju but setuju. They omitted the synonym of preposition in to get a natural translation without transfer the meaning word by word.

\section{Dynamic Equivalence}

\section{Example:}

SLT: He stood on the sidewalk, in the warm October air, and waited for Jose. (P. 10/L. 8)

TLT:Iaberdiri di trotoardalamudaraOktober yang hangat, menunggu Jose. (P. 19/L. 15)

SLT: They stared in silence at the post carpet.... (RJ/P. 20/L. 10)

TLT:Merekamenatapkarpetmewahitutanpabicara... (P. 30/L. 23)

SLT: (...), popped him for two million in a three-wheeler case. (P. 50/L.2)

TLT:(...),menantangnyadengankasusgugatankecelakaantruksenilaidua jutadolar.(P. $68 / \mathrm{L}$. 
SLT: Judge Harkin,in writing, had allowed one hour for each side's opening statement.(P. 70/L.

TLT: Hakim Harkin, secaratertulis, memberikanwaktusatu jam kepadamasingmasingpihakuntukmenyampaikanpidatopembukaan. (P. 92/L. 4)

\section{Discussion:}

The naturalness is a key requirement for Nida's concept. Indeed, he defines the goal of dynamic equivalence as seeking the closest natural equivalent to the source language message. The TL sentences 5, 6, 7 and 8. The English preposition in translated into dalam, tanpa, dengan, dansecara. We can see the relationship between receptor and message would be substantially the same as that which is existed between the original receptor and the message.

There is a little changing in structure of TL sentences from SL sentences. In the sentences 5, where is the sentences .... and waited for Jose ... translated become ... menunggu Jose ... we can see that the word andandfor did not translated or omitted in SL sentences to get the natural translation. Meanwhile, in the sentences 7 ... popped him for the two million in a three-wheeler case ... translated become ... menantangnyadengankasusgugatankecelakaantruksenilaiduajutadolar $\ldots$ so the translation produced a similar response.

\section{Shift} system shift.

Shift classified into four sub-sub categories, class, structure, unit, and intra-

\section{Class Shift}

Example:

SLT: The Company had eighty million in cash snd little debt. (P. 100/L. 7)

TLT: Perusahaan itupunya 80 jutadolar yangtunaidanhanyasedikitutang. (P. 127/L.

SLT: (...), but he was no longer in control. (P. 420/L. 6)

TLT: (...), tapiiatidaklagimemegangkendali. (P. 501/L. 19)

\section{Discussion:}

The example of translations in TLT (9) and (10) are categorized into class shift because there are changing in grammatical class when in cash translated into yang tunai, the word class in as a noun became yang whereas the function word. Meanwhile, when in control translated into memegangkendali, the word class in as a noun became memegang where as a verb.

\section{Structure Shift}

Example:

SLT: He knew the man was likely to disappear in an instant. (P. 140/L. 10) 
TLT:Iatahulaki-lakiitukemungkinanbesarakansegeramenghilang. (P. 173/L. 12). SLT: (...), Vandemeer promised that Trellco would quietly purchase Hadly Brother in two years if Zell wished to unload it. (P. 100/L. 8).

TLT: (...), Vandemeerberjanjibahwadalamduatahun Trello akan membeliHadly Brother secaradiam-diambilazellberniatmelepasnya (P. 127/L 9).

\section{Discussion:}

The example of translation in TLT (11) and (12) are categorized into structure shift because there are changing in grammatical structure between SLT and TLT, in the SLT (11) ininstant translated akansegera and put before menghilang translated from disappear, and SLT (12) intwo years translated into dalamduatahun and put before Trello akanmembeliHadly Brother secaradiam-diam that were translated from Trello would quietly purchaseHadly Brother.

\section{Unit Shift}

Examples:

SLT: "Used to put raising in them ... (P. 60/L. 3).

TLT: "Dulusayamasukkankismis juga ... (P. 79/L. 7).

Discussion:

The examples of translation in TLT (13) categorized into unit shift because there is an explanation in the TLT (13) where is in them translated into masukkankismis juga.

\section{Intra-System Shift}

\section{Examples:}

SLT: (...), and shaggy thick graying hair that parted perfectly in the center and fell in heavy layers to her shoulders. (P. 80/L. 2).

TLT: (...), dankusut yang dibelahtepatdi tengahdantergeraikepuncak. (P. 103/L. 5).

SLT: wek one would end in just a few hours. (P. 100/L. 19).

TLT: Minggupertamaakanberakhirbeberapa jam lagi. (P. 128/L. 1).

SLT: (...), all huddled together in various rooms ... (P. 10/L. 11)

TLT:..., semuanyaberkrumunandalamberbagairuangan ... (P. 20/L. 2).

\section{Discussion:}

The example of translations in TLT (14), (15), and categorized into intrasystem shift because the translation involved selection of a non-corresponding term in the TL system-this is regardless of whether the SL and TL possess systems which approximately correspond formally, such as in the TLT (14) di tengahdantergeraikepundak were translated from in the center and fellin heavy layears to her shoulders. Meanwhile, there are changing from plural became singular when the SLT (15) in just a few hours is not translated into beberapa jam-jam lagi that but into beberapa jam lagi, and the SLT (16) in various rooms is not translated berbagairuang-ruang but into dalamberbagairuangan. 


\section{The English Preposition on and its Indonesian Translations}

The following table is the preposition of the main categories, sub-categories, and sub-sub categories of English Preposition on.Equivalence

\section{Formal Correspondence Equivalence}

Example:

SLT: (...), the firm of Whitney \& Cable \& White \& White was the largest on the Gulf Coast.(P. 10/L. 4).

TLT:(...), biro hukum Whitney \& Cable \& White adalah yang terbesardi Gulf Coast. (P. 19/L.11).

SLT: Speaking into the microphone on the bench ... (P. 30/L. 6).

TLT: Bicarakemikrofondimeja hakim ... (P. 44/L. 11).

\section{Discussion:}

The example of translation in TLT (17) and (18) categorized into formal equivalence because when the SLT translated into TLT, such as in SLT (17) on the Gulf Coast are equal with di Gulf Coast and SLT (18) on the bench translated into dimeja that similar in both form and meaning.

\section{Textual Equivalence}

Example:

SLT: Swanson, an expert on surveillance, was unsure of all the foss. (P. 90/L. 10).

TLT: Swanson, sebagaipakarpengintaian, tidakyakindengansegalakerepotanitu. (P. 115/L. 7).

SLT: Lonnia Shaver just happened to be on jurydown there. (P. 100/L. 2).

TTL: Lonnie Shaver kebetulanmenjadianggotajuri di sana. (P. 127/L. 2)

Discussion:

The example of translation TLT (19) and (20) categorized into textual equivalence because in the SLT (19) on surveillance translated into pakarpengintaian and translation of preposition on omitted in the TLT, and SLT (20) the preposition on in the on the jury is not translated into dalamanggotapenjurian but anggotajuri.

Dynamic Equivalence

\section{Example:}

SLT: Fitch set his water on the mantel ... (P. 20/L. 4)

TLT: Fitch meletakkan air minumnyadiatasperapian ... (P. 30/L. 17)

SLT: State your opinion on the issue of tax dollars being used to find medical care for smoking-related health problems. (P. 40/L. 11)

TLT:Apapendapatandatentanguangpajak yang dipakaiuntukmendanaiperawatanmedisbagimasalah-masalahkesehatan yang berkaitandenganmerokok? (P. 56/L. 11) 
SLT: State your opinion on the issue of banning smoking in all public buildings. (RJ/P. 40/L. 12)

TLT:Apapendapatandamengenailaranganmerokok di gedung-gedungumum ? (P. 56/L. 13)

SLT: (...), and spent many hours on his boat ... (P. 50/L. 1)

TLT: (...), dansukamelewatkanwaktuberjam-jam dalamperahunya ... P.67/L.11)

\section{Discussion:}

The naturalness is a key requirement for Nida's concept. Indeed, he defines the goal of dynamic equivalence as seeking 'the closest natural equivalent to the source language message and message has to be tailored to the receptor's linguistic needs and cultural expectation and aims at complete naturalness of expression. Such as in the TL sentences 21, 22, 23, and 24. The English preposition in translated into di, tentang, mengenai, and dalam. We can see the relationship between receptor and message would be substantially the same as that which is existed between the original receptor and the message.

\section{Shift}

\section{Class Shift}

\section{Example:}

SLT: The image of Lou Dell closing the door on them flashed before his eyes ... (P. 130?:L. 22)

TLT:Bayangan Lou Dell menutuppintumengurungmerekaterlintas di matanya .(P. 162/L. 14).

Discussion:

The example of translation in TLT (25) categorized into class shift because there are changing in grammatical class when on them translated into mengurungmereka, the word class on as a noun became mengurungwhere as a verb.

\section{Structure Shift}

\section{Example:}

SLT: The younger men are kept on the streets to battle the elements ... (P. 140/L. 16)

TLT: Petugas yang lebihmudabiasanyadipasang di jalan ... (P 174/L. 4)

SLT: (...), but he had lived on the Coast for forty years. (P. 250/L. 5)

TLT: (...), tapiiasudahempatpuluhtahuntinggaldi Coast. (P. 30/L. 6) 


\section{Discussion:}

The example of translations in TLT (26) and (27) are categorized into structure shift because there are changing in grammatical structure between SLT and TLT, in the SLT (26) to battle the elements after on the streets is not translated, and the translation became di jalan, in the translation became di jalan, in the SLT (27) on the Coast translated di Coast and put before empatpuluhtahuntranslated from for forty years.

\section{Unit Shift}

Example:

SLT: Rohr rambled on a bit about punitive damages ... (P. 70/L. 12)

TLT: Rohr bicarapanjang-lebarmengenai punitive damage ... (P. 92/L. 3)

Discussion:

This example of translation in TLT (13) categorized into unit shift because there is an explanation in the TLT (28) where is Rohr rambledon translated into Rohr bicarapanjang-lebarmengenai.

\section{Intra-System Shift}

Example:

SLT: (...) but never got the chance to visit on account of his wife. (P. 170/I. 18)

TLT: (...), tapitakpernahiakunjungikarenaadaistrinya. (P. 208/I. 5)

SLT: (...) His luck changed during lunch on Tuesday. (P. 210/I. 3)

TLT:Keberuntungan datang saatmakansianghariselasa (P. 253/I. 8)

\section{Discussion:}

The example of translations in TLT (29) and (30) categorized into intrasystem shift because the translation involved selection of a noun-corresponding term in the TL system-this is regardless of whether the SL and TL possess system which approximately correspond formally, such as in the TLT (29) karenaadaistrinya were translated from on account of his wife, and in the SLT (30) hariselasa translated from onTueday.

\section{The English Preposition at and its Indonesian Translations}

\section{Equivalence}

\section{Formal Correspondence Equivalence}

\section{Example:}

SLT: (...), and at the age of fifty he was checking titles ... (P. 20/L. 15)

TLT: (...), danpadausia lima puluhtahuniamemeriksadaftarperkara ... (P. 32/L. 3). 
SLT: "We've studied the personal at Hadley Brothers ... (P. 130/I. 16)

TLT: "Kami sudahmempelajaripersonaliadi Hadley Brothers ... (P. 162/I. S).

Discussion:

Based on the theory of formal equivalence above, the result of translation or in TLT should be oriented towards the ST structure, which exerts strong influence in determining accuracy and correctness. The SLT (31) at the age translated into padausia, and in the SLT (32) at Hadley Brothers translated into diHadley Brothers are categorized into formal equivalence because the translations equal to the SLT both in the form and meaning.

\section{Textual Equivalence}

\section{Example :}

SLT: (...), and they stare at us constanly.” (P. 110?I. 9)

TLT: (...), danterusmenerusmenatapkita.” (P. 138/I. 8)

SLT: (...), but his job at this point was to guarantee a fair trial. (P. 190/I. 11)

TLT: (...), tapitugasnyasaatiniadalahmenjamin siding yang adil. (P. 231/i. 3)

Discussion:

The concept of shift is the translation of target text cannot be carried out by adhering closely to the linguistic form of the source text (e.g. when a preposition cannot be translated into a preposition. The one of ideal translation is naturalness, using natural form of the receptor language in a way that is appropriate to the kind of text being translated. Based on the translating concepts above, SLT (33) at us did not translate to become kepadakita but kita, and SLT (34) at this point did not translate to become padasaatini but saatini. They omitted the synonym of preposition at to get a natural translation without transfer the meaning word by word.

\section{Dynamic Equivalence}

\section{Example:}

SLT: (...), staring back at the bench as if he knew someone was watching. (P. 140/I. 5)

TLT: (...), memandangketempat hakim, seolah-olahtahusedangdiawasi. (P 173/I. 6).

SLT: It's just that this Biloxi trial has a lot at stake. "(P. 170/I. 5)

TLT:bCumamasalahnya, banyakyangdipertaruhkandalamsidang do Biloxi ini.”(P. 207/I. 11).

SLT: He sipped a beer at a thatched-roof bar ... (P. 170/I. 19)

TLT:Iamenegukbirdi bar beratapjerami ... (P. 208/I. 6).

Discussion:

The naturalness is a key requirement for Nida's concept. Indeed, he defines the goal of dynamic equivalence as seeking 'the closest natural equivalent to the source language message. The TL sentences 35, 36, and 37. The English preposition at translated into ke and $d i$. We can see the relationship between receptor 
and message would be substantially the same as that which is existed between the original receptor and the message.

\section{Shift}

\section{Class Shift}

\section{Example:}

SLT: She was at least six feet tall ... (P. 80/L. 3)

TLT: Tingginyapalingsedikit 180 senti ... (P. 103/L. 6)

\section{Discussion:}

The example of translations in TLT (38) categorized into class shift because there are changing in grammatical class when at least translated into paling sedikit, the word class at as a noun became paling where as an adjective.

\section{Structure Shift}

\section{Example:}

SLT: With a pointed finger, he delicately jabbed at them and said ... (P. 50/L. 17) TLT:Jarinya yang menunjuklembutdiarahkanpadamerekasambilberkata ... (P. 68/L. 4)

SLT: (...), to purchase, at whatever premium necessary, Hadly brothers. (P. 100/L. 4).

TLT: (...), membeli Hadley brothers, berapa punharganya. (P. 127/L. 3)

\section{Discussion:}

The example of translation in TLT (390 and (40) are categorized into structure shift because there are changing in grammatical structure between SLT and TLT, in the SLT (39) at them and said translated into padamereka, where is the conjunction and is omitted in the TLT, and in the SLT (40) at whatever translated into berapa punharganya and put after membeliHadley brothers that were translated from to purchase ..., Hadley Brothers.

\section{Unit Shift}

\section{Example:}

SLT: Most of the jurors were seated at the table with coffee cups..., (P. 200/L. 16) TLT:Sebagianbesaranggotajuri duduk di belakangmeja, dengancangkir kopi ... (P. 243/L. 2)

SLT: there were urgent matters at hand with one of his jurors. (P. 270/L. 2)

TLT: adaurusanmendesak di depanmata, dengansalahsatuanggotajuri. (P. 32/L. 2)

Discussion:

The example of translations in TLT (41) and (42) categorized into unit shift because there is an explanation in the SLT (41) where is at the table translated into di belakangmeja, and in the SLT (42) at hand translated di depanmata. 


\section{Intra-System Shift}

\section{Example:}

SLT: She rolled her eyes up at him as if the rest of the story was just too scandalous. (P. 60/L. 4)

TLT: Iamemutarmatakeatas,seolah-olahsisaceritanyaterlalubauskandal. (P. 79/L. 8) Discussion:

The example of translation in TLT (43) categorized into intra-system shift because the translation involved selection of a noun-corresponding term in the TL system-this is regardless of whether the SL and TL possess systems which approximately correspond formally, there is a changing from plural became singular when the SLT (43) eyes upat him is not translated into mata-matakeatas but matakeatas.

\section{CONCLUSION}

Based on the result of the analysis and the discussion of this study, the following conclusions are: The result of this analysis shows the equivalence and shifts in the Indonesian translation of English prepositions in, on, and at is quit much. It means that the translator of this novel is good enough in mastering the vocabularies in Indonesian language. The equivalence of English prepositions in Indonesian, akan, dengan, di, ke, pada, tanpa, tentang, untuk, di, pada, selama, and mengenai. Their functions for place, allocation, ways, time, and circumstances (events). Assessment of target text by readability, conforming to generic and discourse TL conventions, and judging adequacy of translation for specified purpose.

The professional translators should be improved their skills all the time because language and information always changing in line with the era technology and the cultures. They will be faced the basic problem of the translation in their work. Beside the translator have to preserve the meaning and message of source language text into target language text.

\section{BIBLIOGRAPHY}

Alwi, Hasan. 2003. Tata Bahasa Baku Bahasa Indonesia. EdisiKetiga. Jakarta: BalaiPustaka. 
Baker, Mona. 1998. Routledge Encyclopedia of Translation Studies. New York: Routledge.

Baker, Mona. 1992. In Other Words. New York: Routledge.

Burns, Robert B. 2000. Introduction to Research Methods Fourth Edition. London: Longman.

Duff, Alan. 1990. Translation. New York: Oxford University Press.

Greenbaum, Sidney. 1990. A Student's Grammar of the English Language. England: Pearson Education Limited.

Hatim, Basil. 2001. Teaching and Researching Translation. England: Pearson Education Ltd.

Larson, Mildred A. 1984. Meaning Based Translation. Lanham: University Press of America.

Miles, Matthew B. \& Michael A. Huberman. 1998. Qualitative Data Analysis. London: Sage publication, Inc.

Munday, Jeremy. 2001. Introducing Translation Studies Theories and Application. London: Routledge.

Nababan, M. Rudolf. 2001. TeoriMenerjemahkan Bahasa Inggris. Yogyakarta: Pustaka Pelajar.

Nida, Eugene. 1982. The Theory and Practice of Translation. Lei den: E. J. Brill.

Newmark,Peter. 1988. A Text Book of Translation. United Kingdom: Prentice Hall International, ltd.

Schulte, R and Biguenet, J. 1992. The Theories of Translation. Chicago: The University of Chicago Press. 